\title{
Octachloro- and Hexadecafluoro-Substituted Lanthanide(III) Phthalocyaninates: Synthesis and Spectral Properties
}

\author{
Elena A. Kuzmina, ${ }^{a}$ Tatiana V. Dubinina, ${ }^{\mathrm{a}, \mathrm{b}}{ }$ Nataliya E. Borisova, $^{\mathrm{a}}$ \\ and Larisa G. Tomilova ${ }^{\mathrm{a}, \mathrm{b}}$ \\ Dedicated to Academician Aslan Yu. Tsivadze on the occasion of his Anniversary \\ ${ }^{a}$ M.V. Lomonosov Moscow State University, 119991 Moscow, Russian Federation \\ ' Institute of Physiologically Active Compounds, Russian Academy of Sciences, 142432 Chernogolovka, Russian Federation \\ ${ }^{\circledR}$ Corresponding authorE-mail: dubinina.t.vid@gmail.com
}

\begin{abstract}
Octachloro- and hexadecafluoro-substituted lanthanide(III) monophthalocyaninates, which have not been described earlier, were obtained based on the corresponding nitriles using the template method. The possibility of both thermal and microwave activation of cyclization process was demonstrated. All target compounds were identified by MALDI TOF mass spectrometry, FTIR and ${ }^{1}$ H NMR spectroscopy. Strong downfield lanthanide-induced shifts of signals of aromatic protons were observed in the nuclear magnetic resonance spectra of europium and erbium complexes comparing with diamagnetic lutetium one. Bathochromic shift of the $Q$ band (about $20 \mathrm{~nm}$ ) was observed for hexadecachloro-substituted compounds comparing to octachloro-substituted analogs.
\end{abstract}

Keywords: Phthalocyanine, lanthanide, halogen, template synthesis, spectroscopy.

\section{Октахлор- и гексадекафтор-замещенные фталоцианинаты лантанидов(III): синтез и спектральные свойства}

\author{
Е. А. Кузьмина, ${ }^{a}$ T. В. Аубинина, ${ }^{\mathrm{a}, \mathrm{b}}$ Н. Е. Борисова, ${ }^{a} \Lambda$. Г. Томилова ${ }^{\mathrm{a}, \mathrm{b}}$ \\ ${ }^{\mathrm{a}}$ Московский государственный университет имени М.В. Ломоносова, 119991 Москва, Российская Федерация \\ ${ }^{\mathrm{b}}$ Институт физиологически активных вещчеств РАН, 142432 Черноголовка, Российская Федераџия \\ ${ }^{\circledR}$ E-mail: dubinina.t.vid@gmail.com
}

\begin{abstract}
Неописанные ранее октахлор- и гексадекафтор-замещенные фталоцианинаты лантанидов(III) получены темплатным методом на основе соответствующих нитрилов. Показана возможность активации процесса ичиклизации как термически, так и с помощью микроволнового излучения. Все целевые соединения охарактеризованы методом масс-спектрометрии MALDI TOF, ИК и ${ }^{1} \mathrm{H}$ ЯМР спектроскопии. В ${ }^{1} H$ ЯMP спектрах комплексов парамагнитных европия и эрбия наблюдается сильное смещение сигналов ароматических протонов в слабое поле по сравнению с комплексом диамагнитного лютеция. Батохромный сдвиг $Q$ полосы (около 20 нм) наблюдается для гексадекахлор-замещенных комплексов по сравнению с октахлор-замещенными аналогами.
\end{abstract}

Ключевые слова: Фталоцианин, лантанид, галоген, темплатный синтез, спектроскопия. 


\section{Introduction}

Phthalocyanines and relative compounds attract an interest of investigators in virtue of their chemical and photochemical stability and many possibilities of structural modifications. ${ }^{[1-3]}$ For monophthalocyanine complexes there are three ways for structural transformations: introduction of peripheral and nonperipheral substituents in the macrocycle and the changing of central ions or counterion (in the case of metals with valence $\geq 3$ ). ${ }^{[4,5]}$ The presence of electron-withdrawing functional groups in phthalocyanine leads to shift of the first oxidation potential to the anodic region and corresponding increase of stability, and appearance of $n$-type conductivity. ${ }^{[6-8]}$ Halogensubstituted phthalocyanines are one of the most widely used in practice group of macroheterocycles. ${ }^{[9]}$ One of the most important application areas is organic transistors. ${ }^{[6,7,10-12]}$ The main drawback of these compounds is their low solubility. It can be overcome employing the synthesis of phthalocyanine complexes with the lanthanide(III) ions. The presence of extra ligands and high coordination ability of lanthanides improves solubility of the complexes. Additional advantage of lanthanide phthalocyaninates is the possibility of axial ligand exchange reactions. Using this approach, in our recent publication, ${ }^{[13]}$ the hybrid gold nanoparticles, covered by hexadecachloro-substituted lanthanide phthalocyaninates, were prepared. Increase in reverse saturable absorption effect was observed in hybrid nanoparticles due to their plasmonic properties. Thus, an effective synthesis of novel halogensubstituted lanthanide phthalocyaninates is an important task, as well as a study of their properties. The present paper deals with the synthesis and spectral properties investigation of hexadecafluoro- and octachloro-substituted lanthanide phthalocyaninates. Thanks to their tendency to form the most stable single-decker complexes, ${ }^{[5,14,15]}$ the elements of the middle (Eu) and of the end (Er and $\mathrm{Lu}$ ) of the lanthanide series were chosen as central ions. Noteworthy, that the synthetic approaches to hexadecafluoro- and octachlorosubstituted lanthanide(III) phthalocyaninates were not described earlier in literature.

\section{Experimental}

All reactions were monitored by thin-layer chromatography (TLC) and UV-Vis until complete disappearance of the starting reagents unless otherwise specified. TLC was performed using Merck Aluminium Oxide $\mathrm{F}_{254}$ neutral flexible plates. Electronic absorption (UV-Vis) spectra were recorded on a ThermoSpectronic Helios- $\alpha$ spectrophotometer using quartz cells $(1 \times 1 \mathrm{~cm})$. Matrixassisted laser desorption/ionization time-of-flight (MALDI TOF) mass spectra were taken on a Bruker Autoflex II mass spectrometer with $\alpha$-cyano-4-hydroxycinnamic acid (CHCA) or 2,5-dihydroxybenzoic acid (DHB) as the matrix. The salts, $\mathrm{Eu}(\mathrm{OAc})_{3} \cdot 3 \mathrm{H}_{2} \mathrm{O}, \mathrm{Er}(\mathrm{OAc})_{3} \cdot 4 \mathrm{H}_{2} \mathrm{O}, \mathrm{Lu}(\mathrm{OAc})_{3} \cdot 4 \mathrm{H}_{2} \mathrm{O}$ were dried at $70{ }^{\circ} \mathrm{C}$ for $3 \mathrm{~h}$ immediately before use. 4,5-Dichlorophthalonitrile (99\%, Aldrich), tetrafluorophthalonitrile (95\%, Aldrich) were used as received. FTIR spectra were measured using IR 200 Thermonicolet spectrometer. Spectral resolution: $\Delta \lambda=4 \mathrm{~cm}^{-1} .{ }^{1} \mathrm{H}$ NMR spectra were recorded on a Bruker AVANCE 600 spectrometer $(600.13 \mathrm{MHz})$. Chemical shifts are given in ppm relative to $\mathrm{SiMe}_{4}$.

Preparation of 2,3,9,10,16,17,23,24-octachlorophthalocyaninatoeuropium acetate, $2 \boldsymbol{a}$. Dichlorophthalonitrile $1(158.0 \mathrm{mg}$,
$0.80 \mathrm{mmol}), \mathrm{Eu}(\mathrm{OAc})_{3} \cdot 3 \mathrm{H}_{2} \mathrm{O}(76.4 \mathrm{mg}, 0.20 \mathrm{mmol})$ and 1,8 -diazabicyclo[5.4.0]undec-7-ene $(119 \mu \mathrm{L}, 0.80 \mathrm{mmol})$ were stirred in $3 \mathrm{~mL}$ of boiling isoamyl alcohol for $4 \mathrm{~h}$ (TLC-control: $\mathrm{Al}_{2} \mathrm{O}_{3}, \mathrm{~F}_{254}$, toluene; UV-Vis control: THF). The reaction mixture was cooled to room temperature and a $\mathrm{MeOH}: \mathrm{H}_{2} \mathrm{O}\left(4: 1 \mathrm{~V} / \mathrm{V}, \mathrm{V}_{\text {total }}=100 \mathrm{~mL}\right)$ mixture was added. The precipitate was filtered and washed with a MeOH: $\mathrm{H}_{2} \mathrm{O}(4: 1 \mathrm{~V} / \mathrm{V})$ mixture and dried at $70{ }^{\circ} \mathrm{C}$ to give compound $2 \mathrm{a}(186.0 \mathrm{mg}, 93 \%)$. UV-Vis (THF) $\lambda_{\max }\left(\mathrm{I} / \mathrm{I}_{\max }\right) \mathrm{nm}: 346$ (1.00), 639 (0.58), 677 (0.98). $\mathrm{m} / z$ (MALDI TOF) (\%) 941 (100) $\left[(\mathrm{M}-\mathrm{OAc})^{+}\right]$. IR $(\mathrm{KBr}) v_{\max } \mathrm{cm}^{-1}: 1061-1080(\mathrm{st} \mathrm{C}-\mathrm{Cl}) \mathrm{s}, 1520-1551$ $\left(\gamma\right.$ pyrrole) $\mathrm{m}, 1321-1485(\mathrm{C}-\mathrm{O}) \mathrm{s}, 1551-1643(\mathrm{C}=\mathrm{O}) \mathrm{m} .{ }^{1} \mathrm{H}$ NMR ([D8]THF, $293 \mathrm{~K}) \delta_{\mathrm{H}}$ ppm: $11.19\left(\mathrm{~s}, \mathrm{H}_{\mathrm{Pc}}\right)$.

Preparation of 2,3,9,10,16,17,23,24-octachlorophthalocyaninatoerbium acetate, $2 \boldsymbol{b}$.

Approach A. Dichlorophthalonitrile 1 (158.0 mg, $0.80 \mathrm{mmol}$ ), $\mathrm{Er}(\mathrm{OAc})_{3} \cdot 4 \mathrm{H}_{2} \mathrm{O}(83.0 \mathrm{mg}, 0.20 \mathrm{mmol})$ and 1,8-diazabicyclo[5.4.0] undec-7-ene $(119 \mu \mathrm{L}, 0.80 \mathrm{mmol})$ were stirred in $3 \mathrm{~mL}$ of boiling isoamyl alcohol for $4 \mathrm{~h}$ (TLC-control: $\mathrm{Al}_{2} \mathrm{O}_{3}, \mathrm{~F}_{254}$, toluene; UV-Vis control: THF). The reaction mixture was cooled to room temperature and a $\mathrm{MeOH}: \mathrm{H}_{2} \mathrm{O}\left(4: 1 \mathrm{~V} / \mathrm{V}, \mathrm{V}_{\text {total }}=100 \mathrm{~mL}\right)$ mixture was added. The precipitate was filtered and washed with a $\mathrm{MeOH}: \mathrm{H}_{2} \mathrm{O}(4: 1 \mathrm{~V} / \mathrm{V})$ mixture and dried at $70{ }^{\circ} \mathrm{C}$ to give compound $\mathbf{2 b}(173.0 \mathrm{mg}, 85 \%)$. UV-Vis (THF) $\lambda_{\max }\left(\mathrm{I} / \mathrm{I}_{\max }\right) \mathrm{nm}: 349(0.56), 612(0.26), 676(1.00)$. $\mathrm{m} / \mathrm{z}$ (MALDI TOF) (\%) $1145(100)$ [(M-OAc+CHCA) $\left.{ }^{+}\right]$. IR (KBr) $v_{\max } \mathrm{cm}^{-1}: 1063-1080(\mathrm{st} \mathrm{C}-\mathrm{Cl}) \mathrm{s}, 1520-1599(\gamma$ pyrrole $) \mathrm{s}, 1321-$ $1456(\mathrm{C}-\mathrm{O}) \mathrm{s}, 1520-1599(\mathrm{C}=\mathrm{O}) \mathrm{s} .{ }^{1} \mathrm{H}$ NMR ([D8]THF, $\left.293 \mathrm{~K}\right) \delta_{\mathrm{H}}$ ppm: $38.21\left(\mathrm{~s}, \mathrm{H}_{\mathrm{pc}}\right)$.

Approach B. The mixture of dichlorophthalonitrile $\mathbf{1}$ (158.0 mg, $0.80 \mathrm{mmol}), \mathrm{Er}(\mathrm{OAc})_{3} \cdot 4 \mathrm{H}_{2} \mathrm{O}(83.0 \mathrm{mg}, 0.20 \mathrm{mmol})$ and 1,8-diazabicyclo[5.4.0]undec-7-ene $(119 \mu \mathrm{L}, 0.80 \mathrm{mmol})$ in $3 \mathrm{~mL}$ of isoamyl alcohol was irradiated in a microwave oven $(450 \mathrm{~W})$ during $8 \mathrm{~min}$. The reaction mixture was cooled to room temperature and a $\mathrm{MeOH}: \mathrm{H}_{2} \mathrm{O}\left(4: 1 \mathrm{~V} / \mathrm{V}, \mathrm{V}_{\text {total }}=100 \mathrm{~mL}\right)$ mixture was added. The precipitate was filtered and washed with a $\mathrm{MeOH}: \mathrm{H}_{2} \mathrm{O}(4: 1 \mathrm{~V} / \mathrm{V})$ mixture and dried at $70{ }^{\circ} \mathrm{C}$ to give compound $\mathbf{2 b}(169.0 \mathrm{mg}, 83 \%)$. The characteristics were identical with those obtained by method (A).

Preparation of 2,3,9,10,16,17,23,24-octachlorophthalocyaninatolutetium acetate, 2c. Dichlorophthalonitrile $1(158.0 \mathrm{mg}$, $0.80 \mathrm{mmol}), \mathrm{Lu}(\mathrm{OAc})_{3} \cdot 3 \mathrm{H}_{2} \mathrm{O}(85.6 \mathrm{mg}, 0.20 \mathrm{mmol})$ and $1,8-\mathrm{di}-$ azabicyclo[5.4.0]undec-7-ene $(119 \mu \mathrm{L}, 0.80 \mathrm{mmol})$ were stirred in $3 \mathrm{~mL}$ of boiling isoamyl alcohol for $4 \mathrm{~h}$ (TLC-control: $\mathrm{Al}_{2} \mathrm{O}_{3}, \mathrm{~F}_{254}$, toluene; UV-Vis control: THF). The reaction mixture was cooled to room temperature and a $\mathrm{MeOH}: \mathrm{H}_{2} \mathrm{O}\left(4: 1 \mathrm{~V} / \mathrm{V}, \mathrm{V}_{\text {total }}=100 \mathrm{~mL}\right)$ mixture was added. The precipitate was filtered and washed with a $\mathrm{MeOH}: \mathrm{H}_{2} \mathrm{O}(4: 1 \mathrm{~V} / \mathrm{V})$ mixture and dried at $70{ }^{\circ} \mathrm{C}$ to give compound $2 \mathrm{c}(200.0 \mathrm{mg}, 98 \%)$. UV-Vis (THF) $\lambda_{\text {max }}\left(\mathrm{I} / \mathrm{I}_{\max }\right) \mathrm{nm}: 349$ (0.60), 612 (0.30), 676 (1.00). $m / z$ (MALDI TOF) (\%) 1153 (100) [(M-OAc+CHCA $\left.)^{+}\right]$. IR (KBr) $v_{\max } \mathrm{cm}^{-1}: 1063-1080(\mathrm{st} \mathrm{C}-\mathrm{Cl}) \mathrm{s}$, $1518-1556(\gamma$ pyrrole $) \mathrm{m}, 1322-1454(\mathrm{C}-\mathrm{O}) \mathrm{s}, 1556-1641(\mathrm{C}=\mathrm{O})$ m. ${ }^{1} \mathrm{H}$ NMR ([D8]THF, $\left.293 \mathrm{~K}\right) \delta_{\mathrm{H}}$ ppm: $9.54\left(\mathrm{~s}, \mathrm{H}_{\mathrm{pc}}\right)$.

Preparation of $1,2,3,4,8,9,10,11,15,16,17,18,22,23,24,25$ hexadecafluorophthalocyaninatoeuropium acetate, $4 \boldsymbol{a}$. The mixture of tetrafluorophthalonitrile $(200.0 \mathrm{mg}, 1.00 \mathrm{mmol}), \mathrm{Eu}(\mathrm{OAc})_{3} \cdot 3 \mathrm{H}_{2} \mathrm{O}$ (95.5 $\mathrm{mg}, 0.25 \mathrm{mmol})$ and hydroquinone $(55 \mathrm{mg}, 0.50 \mathrm{mmol})$ was transferred into a flask and heated at $180^{\circ} \mathrm{C}$ for $30 \mathrm{~min}$ (TLCcontrol: $\mathrm{SiO}_{2}, \mathrm{~F}_{254}$, toluene; UV-Vis control: THF). The reaction mixture was cooled to room temperature and a $\mathrm{MeOH}: \mathrm{H}_{2} \mathrm{O}(4: 1$ $\left.\mathrm{V} / \mathrm{V}, \mathrm{V}_{\text {total }}=100 \mathrm{~mL}\right)$ mixture was added. The precipitate was filtered and washed with a $\mathrm{MeOH}: \mathrm{H}_{2} \mathrm{O}(4: 1 \mathrm{~V} / \mathrm{V})$ mixture and dried at $70{ }^{\circ} \mathrm{C}$ to give compound $4 \mathbf{a}(65.5 \mathrm{mg}, 26 \%)$. UV-Vis (THF) $\lambda_{\text {max }}$ $\left(\mathrm{I} / \mathrm{I}_{\max }\right) \mathrm{nm}: 400$ (0.60), 612 (0.30), 680 (1.00). $\mathrm{m} / \mathrm{z}$ (MALDI TOF) (\%) $1066(100)\left[(\mathrm{M}-\mathrm{OAc}-4 \mathrm{~F}+\mathrm{CHCA})^{+}\right]$. IR $(\mathrm{KBr}) \mathrm{v}_{\max } \mathrm{cm}^{-1}: 1184$ 1321 (st C-F) m, 1578 ( $\gamma$ pyrrole) s, 1321-1458 (C-O) s, 1578 $(\mathrm{C}=\mathrm{O}) \mathrm{s}$.

Preparation of $1,2,3,4,8,9,10,11,15,16,17,18,22,23,24,25$ hexadecafluorophthalocyaninatoerbium acetate, $4 \boldsymbol{b}$. The mixture 
of tetrafluorophthalonitrile 3 (200.0 mg, $1.00 \mathrm{mmol}), \mathrm{Er}(\mathrm{OAc})_{3} \cdot 3 \mathrm{H}_{2} \mathrm{O}$ $(104.0 \mathrm{mg}, 0.25 \mathrm{mmol})$ and hydroquinone $(55.0 \mathrm{mg}, 0.50 \mathrm{mmol})$ was transferred into a flask and heated at $180{ }^{\circ} \mathrm{C}$ for $20 \mathrm{~min}$ (TLCcontrol: $\mathrm{Al}_{2} \mathrm{O}_{3}, \mathrm{~F}_{254}$, toluene; UV-Vis control: THF). The reaction mixture was cooled to room temperature and a $\mathrm{MeOH}: \mathrm{H}_{2} \mathrm{O}(4: 1$ $\mathrm{V} / \mathrm{V}, \mathrm{V}_{\text {total }}=100 \mathrm{~mL}$ ) mixture was added. The precipitate was filtered and washed with a $\mathrm{MeOH}: \mathrm{H}_{2} \mathrm{O}(4: 1 \mathrm{~V} / \mathrm{V})$ mixture and dried at $70{ }^{\circ} \mathrm{C}$ to give compound $4 \mathbf{b}(49.0 \mathrm{mg}, 19 \%)$. UV-Vis (THF) $\lambda$ $\left(\mathrm{I} / \mathrm{I}_{\max }\right) \mathrm{nm}: 400$ (1.00), $682(0.50) . m / z$ (MALDI TOF) (\%) 877 (100) $\left[(\mathrm{M}-\mathrm{OAc}-5 \mathrm{~F})^{+}\right], 893(50)\left[(\mathrm{M}-\mathrm{OAc}-4 \mathrm{~F})^{+}\right], 1082(70)[(\mathrm{M}-$ $\left.\mathrm{OAc}-4 \mathrm{~F}+\mathrm{CHCA})^{+}\right], 1099$ (70) [(M-OAc-3F+CHCA $\left.)^{+}\right]$. IR $(\mathrm{KBr})$ $v_{\max } \mathrm{cm}^{-1}: 1182-1315$ (st C-F) m, 1497-1593 ( $\gamma$ pyrrole) $\mathrm{m}, 1315-$ $1446(\mathrm{C}-\mathrm{O}) \mathrm{s}, 1593-1612(\mathrm{C}=\mathrm{O}) \mathrm{s}$.

Preparation of $1,2,3,4,8,9,10,11,15,16,17,18,22,23,24,25$ hexadecafluorophthalocyaninatolutetium acetate, 4c. The mixture of tetrafluorophthalonitrile $3(200.0 \mathrm{mg}, 1.0 \mathrm{mmol}), \mathrm{Lu}(\mathrm{OAc})_{3} \cdot 3 \mathrm{H}_{2} \mathrm{O}$ $(106.0 \mathrm{mg}, 0.25 \mathrm{mmol})$ and hydroquinone $(55.0 \mathrm{mg}, 0.50 \mathrm{mmol})$ was transferred into a flask and heated at $180{ }^{\circ} \mathrm{C}$ for $20 \mathrm{~min}$ (TLCcontrol: $\mathrm{Al}_{2} \mathrm{O}_{3}, \mathrm{~F}_{254}$, toluene; UV-Vis control: THF). The reaction mixture was cooled to room temperature and a $\mathrm{MeOH}: \mathrm{H}_{2} \mathrm{O}(4: 1$ $\left.\mathrm{V} / \mathrm{V}, \mathrm{V}_{\text {total }}=100 \mathrm{~mL}\right)$ mixture was added. The precipitate was filtered and washed with a $\mathrm{MeOH}: \mathrm{H}_{2} \mathrm{O}(4: 1 \mathrm{~V} / \mathrm{V})$ mixture and dried at $70{ }^{\circ} \mathrm{C}$ to give compound $4 \mathbf{c}(31.0 \mathrm{mg}, 12 \%)$. UV-Vis (THF) $\lambda_{\text {max }}$ $\left(\mathrm{I} / \mathrm{I}_{\max }\right) \mathrm{nm}: 407$ (1.00), 680 (0.60). m/z (MALDI TOF) (\%) 981 (50) $\left[(\mathrm{M}-3 \mathrm{~F})^{+}\right], 1115(100)\left[(\mathrm{M}-\mathrm{OAc}+\mathrm{DHB}-\mathrm{OH})^{+}\right] . \mathrm{IR}(\mathrm{KBr}) v_{\max } \mathrm{cm}^{-1}$ : 1182-1269 (st C-F) m, 1562 ( $\gamma$ pyrrole) s, 1410-1458 (C-O) s, $1562-1614(\mathrm{C}=\mathrm{O}) \mathrm{s}$.

\section{Results and Discussion}

Octachloro-substituted lanthanide(III) phthalocyaninates were obtained starting from 4,5-dichlorophthalonitrile 1 by the template synthesis (Scheme 1). Selectivity of the monophthalocyanine formation was provided by 1,8-diazabicyclo[5.4.0] undec-7-ene (DBU), coordination of which to the lanthanide central ion results in steric hindrance and prevents undesirable formation of the sandwich-type complexes. ${ }^{[16]}$ Moreover, the use of DBU as a base is preferred rather than employment of alkoxide ions because of the possibility of nucleophilic substitution, which is typical for the electron-deficient systems. ${ }^{[17,18]}$ Absence of sandwich-type by-products was proven by TLC, UV-Vis and MALDI TOF methods. The products of oligomerization of starting nitrile were removed by washing with $\mathrm{MeOH}$. For erbium complex $\mathbf{2} \mathbf{b}$ the cyclization process was activated thermally or using microwave irradiation. In comparison with thermally activated process, microwave activation allows to decrease the time of synthesis from
$4 \mathrm{~h}$ to $8 \mathrm{~min}$. It is the first example of microwave-assisted synthesis of lanthanide monophthalocyaninate. In literature, the microwave-assisted synthesis was described only for double-decker lanthanide phthalo- and naphthalocyaninates. ${ }^{[19-22]}$

Attempts to obtain hexadecafluoro-substituted complexes from nitrile $\mathbf{3}$ in boiling isoamyl alcohol were unsuccessful. Probably, it can be explained by tendency of fluorine groups to nucleophilic substitution (for e.g. by $i$-AmO-). This process prevents the further cyclization due to the steric effect of four isoamyloxy groups. Procedures for preparation hexadecafluoro-substituted complexes, which were described in literature (central metals $-\mathrm{Zn}, \mathrm{Cu}, \mathrm{Ru}),{ }^{[23,24]}$ presuppose the synthesis in the melt of initial nitrile 3 . In a present case, this approach does not give target compounds 4 .

Since the formation of phthalocyanine includes the reduction stage, we decided to use hydroquinone as a reducing agent and at the same time the reaction media (Scheme 2). The hydroquinone was earlier utilized in the synthesis metal-free phthalocyanines. ${ }^{[25]}$

The yields of target complexes 4a-c are comparable with those presented in literature for zinc and transition metal complexes. ${ }^{[23,24]}$ It is noteworthy that solubility of hexadecafluoro-substituted complexes $\mathbf{4 a - c}$ in common organic solvents is lower, than solubility of octachloro- and hexadecahloro-substituted analogues.

All the compounds obtained were characterized by the MALDI TOF mass spectrometry. The peaks of molecular ions were not observed. Instead of this, the cleavage of axial acetate and its substitution to the molecule of matrix under laser ionization were observed. It can be explained by high mobility of axial ions in lanthanide monophthalocyaninates. As an example, the mass spectrum of complex $\mathbf{2 b}$ is shown in Figure 1. This phenomenon is typical for lanthanide(III) phthalocyaninates and their analogs. ${ }^{[14,26-28]}$

The fragmentation of axial ligand shows the possibility of the ligand exchange during the formation of hybrid materials or sandwich-type complexes. ${ }^{[13,29]}$

In order to prove the presence of axial acetates and other important structural moieties in target complexes 2 and 4 , the FTIR spectra were measured. Stretching vibrations of $\mathrm{C}-\mathrm{Cl}$ bonds for compounds $\mathbf{2}$ were observed in the region of 1061-1080 $\mathrm{cm}^{-1}$. Corresponding bands of C-F bonds for compounds 4 were observed in the region of $1182-1321 \mathrm{~cm}^{-1}$. Skeletal vibrations of pyrrole fragments occupy the region from 1497 to $1599 \mathrm{~cm}^{-1}$. The bands at $1315-1485 \mathrm{~cm}^{-1}$ and at

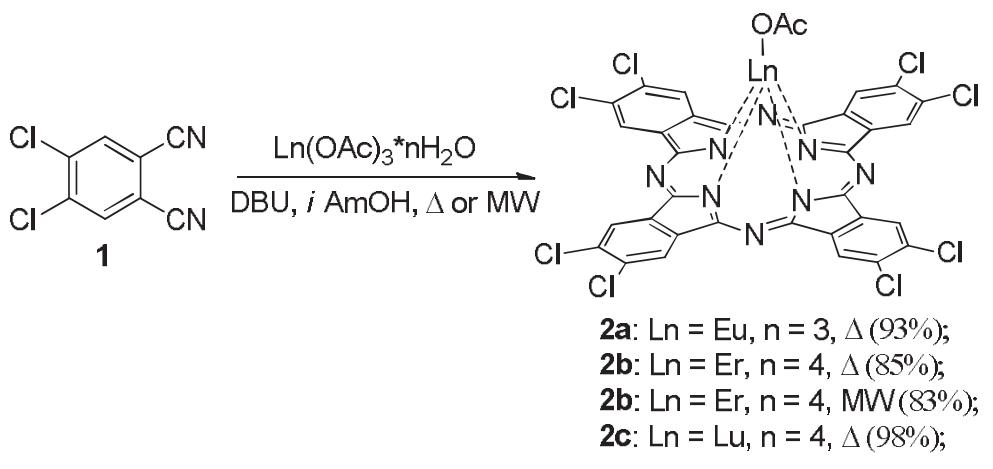

Scheme 1. Synthesis of octachloro-substituted lanthanide phthalocyaninates $\mathbf{2 a - c .}$ 
<smiles>N#Cc1c(F)c(F)c(F)c(F)c1C#N</smiles>

3

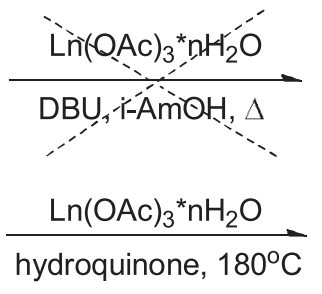

hydroquinone, $180^{\circ} \mathrm{C}$

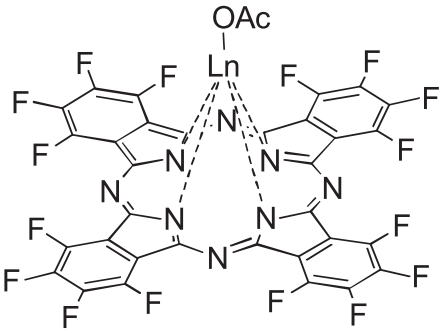

4a: $\operatorname{Ln}=E u, n=3, \Delta(26 \%)$;

4b: $L n=E r, n=4, \Delta(19 \%)$;

4c: $\operatorname{Ln}=\mathrm{Lu}, \mathrm{n}=4, \Delta(12 \%)$.

Scheme 2. Synthesis of hexadecafluoro-substituted lanthanide phthalocyaninates 4a-c.

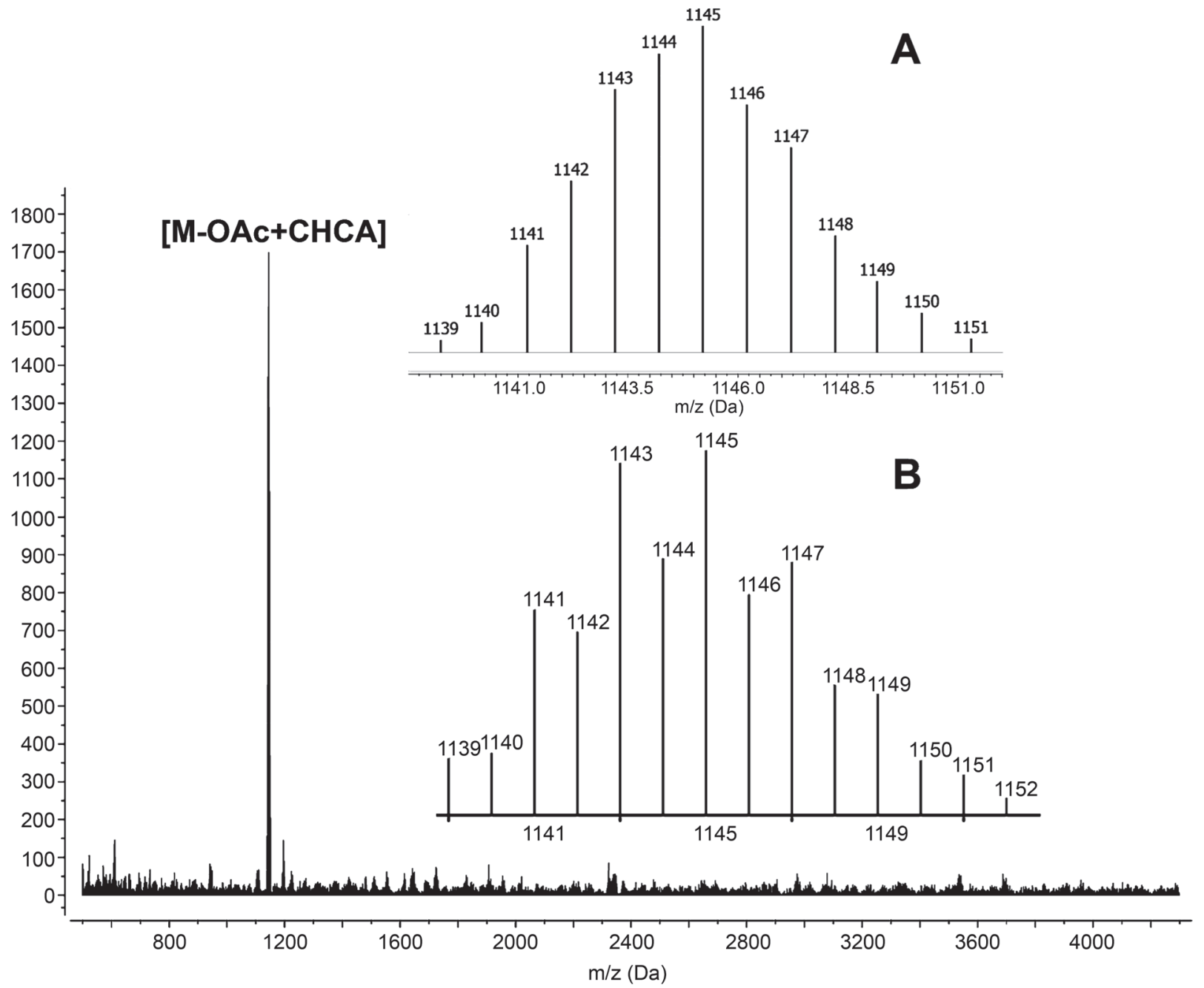

Figure 1. MALDI TOF mass spectrum of complex $\mathbf{2 b}$, isotopic pattern (inset A) and simulated MS pattern for [M-OAc+CHCA] ion (inset B).

$1520-1643 \mathrm{~cm}^{-1}$ were assigned to $\mathrm{C}-\mathrm{O}$ and $\mathrm{C}=\mathrm{O}$ vibrations of the acetate groups, respectively (Figure 2).

Notably, the same values were observed for acetates in literature ${ }^{[30]}$ and for perchlorinated phthalocyaninates of lanthanides, which were reported by us earlier. ${ }^{[13]}$

In order to reach a better signal resolution in the ${ }^{1} \mathrm{H}$ NMR spectra of phthalocyanines 2a-c, a polar coordinating solvent, namely, [D8]THF was used. The employment of [D5]Py is undesirable because of the presumable overlapping of aromatic signals with the solvent ones. In the case of diamagnetic lutetium complex 2c, aromatic protons $\mathrm{H}_{\mathrm{Pc}}$ are shifted downfield, comparing to phthalocyanine complexes without peripheral substituents $(\mathbf{P c L u C l})$ or bearing electron-donating groups ( ${ }^{\text {EtPcLuOAc and }{ }^{B u} \text { PcLuOAc) }}$ (Table 1). This tendency remains for complexes with paramagnetic central ions. 

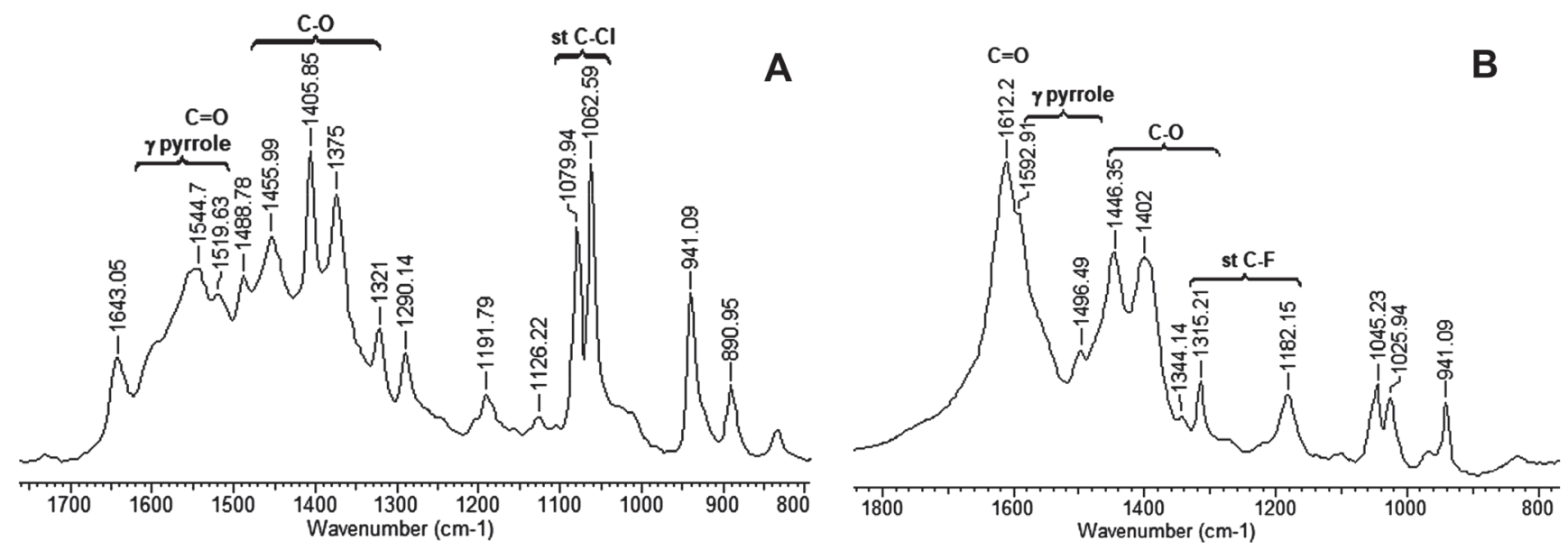

Figure 2. FTIR spectra of erbium phthalocyaninates $\mathbf{2 b}(\mathrm{A})$ and $\mathbf{4 b}(\mathrm{B})$ in $\mathrm{KBr}$.

Table 1. ${ }^{1} \mathrm{H}$ NMR data of lanthanide(III) phthalocyaninates.

\begin{tabular}{|c|c|c|}
\hline Compound & $\delta_{\mathrm{H}} \mathrm{H}_{\mathrm{Pc}}, \mathrm{ppm}$ & Solvent \\
\hline $2 a$ & 11.19 & [D8]THF \\
\hline $2 b$ & 38.21 & [D8]THF \\
\hline $2 c$ & 9.54 & [D8]THF \\
\hline${ }^{\mathrm{Et}} \mathrm{PcEuOAc}{ }^{[31]}$ & 9.90 & $\mathrm{CDCl}_{3}:[\mathrm{D} 6] \mathrm{DMSO}(3: 1, \mathrm{~V}: \mathrm{V})$ \\
\hline${ }^{\mathrm{Bu} P c E u O A c}{ }^{[31]}$ & 9.90 & $\mathrm{CDCl}_{3}:[\mathrm{D} 6] \mathrm{DMSO}(3: 1, \mathrm{~V}: \mathrm{V})$ \\
\hline${ }^{E t P c E r O A c}{ }^{[31]}$ & 23.07 & $\mathrm{CDCl}_{3}:[\mathrm{D} 6] \mathrm{DMSO}(3: 1, \mathrm{~V}: \mathrm{V})$ \\
\hline${ }^{\mathrm{Bu}} \mathrm{PcErOAc}{ }^{[31]}$ & 23.14 & $\mathrm{CDCl}_{3}:[\mathrm{D} 6] \mathrm{DMSO}(3: 1, \mathrm{~V}: \mathrm{V})$ \\
\hline${ }^{E t P c L u O A c}{ }^{[31]}$ & 9.20 & $\mathrm{CDCl}_{3}:[\mathrm{D} 6] \mathrm{DMSO}(3: 1, \mathrm{~V}: \mathrm{V})$ \\
\hline${ }^{\mathrm{Bu}} \mathrm{PcLuOAc}{ }^{[31]}$ & 9.20 & $\mathrm{CDCl}_{3}:[\mathrm{D} 6] \mathrm{DMSO}(3: 1, \mathrm{~V}: \mathrm{V})$ \\
\hline $\mathrm{PcErCl}^{[32]}$ & 18.81 & [D6]DMSO \\
\hline $\mathrm{PcLuCl}^{[32]}$ & 9.44 & [D6]DMSO \\
\hline
\end{tabular}

The presence of a paramagnetic central ion in complexes $\mathbf{2} \mathbf{a}$ and $\mathbf{2} \mathbf{b}$ results in a downfield shift of the aromatic proton signals comparing to lutetium analog $\mathbf{2 c}$. The most downfield shifted signal of $\mathrm{H}_{\mathrm{P}_{\mathrm{c}}}$ protons of erbium complex 2c lies at $38.21 \mathrm{ppm}$. Noteworthy, the best resolved ${ }^{1} \mathrm{H}$ NMR spectrum of $\mathbf{2 b}$ was measured at $60{ }^{\circ} \mathrm{C}$. However, the signal of $\mathrm{H}_{\mathrm{Pc}}$ protons is shifted upfield to $31.89 \mathrm{ppm}$ comparing to the spectrum, which was measured at $20^{\circ} \mathrm{C}$.

In the UV-Vis spectra of lanthanide complexes $\mathbf{2}$ and $\mathbf{4}$ two absorption bands are observed: $B$ band (at 350-400 nm) and $Q$ band (at 670-680 nm). As it was shown earlier for other lanthanide monophthalocyaninates, ${ }^{[13,14]}$ the lanthanide ion nature does not influence the $Q$ band position (Table 2).

In comparison with hexadecachloro-substituted complexes ( $\left.{ }^{\mathbf{C 1 1}} \mathbf{P c L n O A c}\right)$, which were described by us earlier, ${ }^{[13]}$ hexadecafluoro-substituted analogs $\mathbf{4 a - c}$ possess hypsochromic shift of $Q$ band (Table 2). It can be explained by strong negative inductive effect $\left(I^{-}\right)$of fluorine groups.

The presence of chlorine atoms in $\alpha$-and $\beta$-positions results in bathochromic shift of the $Q$ band (about $20 \mathrm{~nm}$ ) for hexadecachloro-substituted compounds comparing to octachloro-substituted analogs 2 (Figure 3).
Table 2. UV-Vis data in THF.

\begin{tabular}{ccc}
\hline Compound & $B$ band, $\mathrm{nm}$ & $Q$ band, $\mathrm{nm}$ \\
\hline 2a & 346 & 677 \\
2b & 349 & 676 \\
2c & 349 & 676 \\
4a & 400 & 680 \\
4b & 400 & 682 \\
4c & 407 & 680 \\
${ }^{{ }^{116} \text { PcEuOAc }}{ }^{[13]}$ & 378 & 696 \\
${ }^{{ }^{C 116} \text { PcErOAc }}{ }^{[13]}$ & 361 & 696 \\
${ }^{{ }^{116} \text { PcLuOAc }}{ }^{[13]}$ & 363 & 699 \\
\hline
\end{tabular}

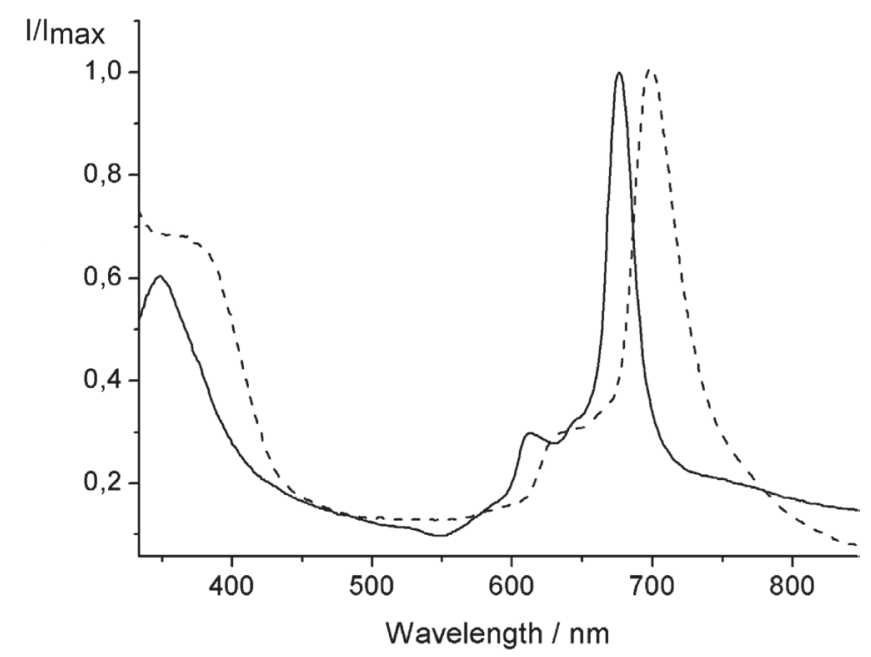

Figure 3. UV-Vis spectra of complex $2 \mathrm{c}$ (solid line) and hexadecachloro-substituted lutetium phthalocyaninate ${ }^{[13]}$ (dashed line) in THF.

\section{Conclusions}

Novel octachloro- and hexadecafluoro-substituted lanthanide(III) phthalocyaninates were obtained using 
the template method on the basis of corresponding phthalonitriles. In comparison with thermally activated synthesis of octachloro-substituted erbium phthalocyaninate, the employment of microwave assisted approach allows to decrease the time of synthesis from $4 \mathrm{~h}$ to $8 \mathrm{~min}$. For the first time the accessibility of perfluorinated lanthanide(III) phthalocyaninates was reached by the use of hydroquinone as a reducing agent and reaction medium. Target compounds were identified by MALDI TOF mass spectrometry, FTIR spectroscopy. In the case of octachloro-substituted complexes, the ${ }^{1} \mathrm{H}$ NMR spectra were measured revealing strong downfield lanthanideinduced shifts of signals of aromatic protons in europium and erbium complexes comparing with the diamagnetic lutetium one. The most downfield shifted signal of aromatic protons of erbium complex lies at $38.21 \mathrm{ppm}$. The influence of the nature of halogens and type of substitution on the position of the UV-Vis absorption maxima was shown. The $Q$ bands are bathochromically shifted in a row: octachloro- < hexadecafluoro- $<$ hexadecachloro-substituted complexes.

Acknowledgements. We are grateful to the Russian Scientific Fund (Grant 17-13-01197) for main support of this research.

\section{References}

1. Dubinina T.V., Tomilova L.G., Zefirov N.S. Russ. Chem. Rev. 2013, 82,865 .

2. Donzello M.P., Ercolani C., Novakova V., Zimcik P., Stuzhin P.A. Coord. Chem. Rev. 2016, 309, 107-179.

3. Kobayashi N., Fukuda T. Recent Progress in Phthalocyanine Chemistry: Synthesis and Characterization. In: Functional Dyes, Ch. 1 (Sung-Hoon Kim, Ed.). Elsevier Science, 2006. $650 \mathrm{p}$.

4. Lukyanets E.A., Nemykin V.N. J. Porphyrins Phthalocyanines 2010, 14, 1-40.

5. Pushkarev V.E., Tomilova L.G., Tomilov Y.V. Russ. Chem. Rev. 2008, 77, 875 .

6. Kim K., Kwak T.H., Cho M.Y., Lee J.W., Joo J. Synth. Met. 2008, 158, 553-555.

7. Yang R.D., Park J., Colesniuc C.N., Schuller I.K., Royer J.E., Trogler W.C., Kummel A.C. J. Chem. Phys. 2009, 130, 164703.

8. Schlettwein D., Woehrle D., Karmann E., Melville U. Chem. Mater. 1994, 6, 3-6.

9. Gregory P. J. Porphyrins Phthalocyanines 2000, 4, 432-437.

10. Roberts M.E., Mannsfeld S.C.B., Tang M.L., Bao Z. Chem. Mater. 2008, 20, 7332-7338.
11. Liu S., Becerril H.A., LeMieux M.C., Wang W.M., Oh J.H., Bao Z. Adv. Mater. 2009, 21, 1266-270.

12. Wei Z., Xu W., Hu W., Zhu D. Langmuir 2009, 25, 3349-3351.

13. Kuzmina E.A., Dubinina T.V., Zasedatelev A.V., Baranikov A.V., Makedonskaya M.I., Egorova T.B., Tomilova L.G. Polyhedron 2017, 135, 41-48.

14. Dubinina T.V., Paramonova K.V., Trashin S.A., Borisova N.E., Tomilova L.G., Zefirov N.S. Dalton Trans. 2014, 43, 2799 2809.

15. Pushkarev V.E., Tomilova L.G., Nemykin V.N. Coord. Chem. Rev. 2016, 319, 110-179.

16. Gorbunova Y.G., Lapkina L.A., Martynov A.G., Biryukova I.V., Tsivadze A.Y. Russ. J. Coord. Chem. 2004, 30, 245-251.

17. Mørkved E.H., Afseth N.K., Kjøsen H. J. Porphyrins Phthalocyanines 2006, 10, 1301-1308.

18. Hamdoush M., Ivanova S.S., Koifman O.I., Kos'kina M., Pakhomov G.L., Stuzhin P.A. Inorg. Chim. Acta 2016, 444, 81-86.

19. Kogan E.G., Ivanov A.V., Tomilova L.G., Zefirov N.S. Mendeleev Commun. 2002, 12, 54-55.

20. Dubinina T.V., Piskovoi R.A., Tolbin A.Y., Pushkarev V.E., Vagin M.Y., Tomilova L.G., Zefirov N.S. Russ. Chem. Bull. 2008, 57, 1912-1919.

21. Dubinina T.V., Pushkarev V.E., Trashin S.A., Paramonova K.V., Tomilova L.G. Macroheterocycles 2012, 5, 366-370.

22. Pushkarev V.E., Ivanov A.V., Zhukov I.V., Shulishov E.V., Tomilov Y.V. Russ. Chem. Bull. 2004, 53, 554-560.

23. Hiller S., Schlettwein D.R., Armstrong N., Wohrle D. J. Mater. Chem. 1998, 8, 945-954.

24. Christendat D., David M.-A., Morin S., Lever A.B.P., Kadish K.M., Shao J. J. Porphyrins Phthalocyanines 2005, 9, 626-636.

25. Gurol I., Ahsena V., Bekaroglu O. J. Chem. Soc., Dalton Trans. 1994, 497-500.

26. Dubinina T.V., Ivanov A.V., Borisova N.E., Trashin S.A., Gurskiy S.I., Tomilova L.G., Zefirov N.S. Inorg. Chim. Acta 2010 , 363, 1869-1878.

27. Dubinina T.V., Dyumaeva D.V., Trashin S.A., Sedova M.V., Karpo A.B., Krasovskii V.I., Tomilova L.G. Macroheterocycles 2012, 5, 149-156.

28. Dubinina T.V., Dyumaeva D.V., Trashin S.A., Sedova M.V., Dudnik A.S., Borisova N.E., Tomilova L.G., Zefirov N.S. Dyes Pigm. 2013, 96, 699-704.

29. Dubinina T.V., Kosov A.D., Petrusevich E.F., Maklakov S.S., Borisova N.E., Tomilova L.G., Zefirov N.S. Dalton Trans. 2015, 44, 7973-7981.

30. Nakamoto K. Infrared and Raman Spectra of Inorganic and Coordination Compounds. A Wiley-Interscience Publication John Wiley and Sons, 1986.

31. Pushkarev V.E., Breusova M.O., Shulishov E.V., Tomilov Y.V. Russ. Chem. Bull. 2005, 54, 2087-2093.

32. Jiazan N., Feng S., Zhenxiang L., Shaoming Y. Inorg. Chim. Acta 1987, 139, 165-168. 